\title{
ANALISIS PEMAHAMAN KONSEP IPA PADA SISWA SMP DENGAN KEGIATAN PRAKTIKUM
}

\author{
Nidya' Ul Afifah ${ }^{1}$, Tarisa Putri Octaviani ${ }^{2}$, Umi Sholikhah ${ }^{3}$ \\ 1,2,3 Pendidikan IPA, FKIP, Universitas Tidar, Magelang, 56112, Indonesia \\ Email: ${ }^{1}$ nidyaafifah01@gmail.com
}

Diajukan: 1 Agustus 2021; Diterima: 2 September 2021; Diterbitkan: 30 Oktober 2021

\begin{abstract}
Abstrak: Tujuan penlitian ini ialah untuk memahami bagimanakah pemahaman pada konsep materi khusunya pada siswa jenjang SMP dengan kegiatan praktikum dalam pembelajaran IPA. Penelitan ini menggunakan metode pengumpulan data kuesioner angket dengan menggunakn teknik Self- Administered Questionnaires. Pengambilan data pada kuesioner dengan jumlah responden sebanyak 30 siswa jenjang SMP di wilayah Kabupaten Magelang. Hasil dari penelitian diperoleh dari $100 \%$ siswa menyatakan bahwa kegiatan praktikum pada pembelajaran IPA membantu dalam pemahaman konsep pada materi pembelajaran. Dari hasil kuesioner juga menunjukan bahwa sebagian besar siswa dapat tuntas dalam menjawab kuesioner. Dari hasil penelitian juga diperoleh bahwa melalui kegiatan praktikum juga dapat membentuk pribadi yang bertanggung jawab dan membantu persamaan persepsi antara siswa dan guru. Diperoleh berbagai hal dari kegiatan praktikum pada pembelajaran IPA. Hal itu dikarenakan pada kegiatan praktikum, siswa memperoleh gambaran secara konkret keadaan atau proses yang terjadi.
\end{abstract}

Kata kunci : kegiatan praktikum, metode pengisian kuesioner, pemahaman

Abstract: The purpose of this study is to understand how to understand the concept of material, especially for junior high school students with practical activities in science learning. This research uses a questionnaire questionnaire data collection method using the Self-Administered Questionnaire technique. Collecting data on the questionnaire with the number of respondents as many as 30 junior high school students in the Magelang Regency area. The results of the study were obtained from 100\% of students stating that practical activities in science learning helped in understanding concepts in learning materials. The results of the questionnaire also showed that most of the students were able to complete answering the questionnaire. From the results of the study, it was also found that through practicum activities can also form a responsible person and help share perceptions between students and teachers. Various things were obtained from practical activities in science learning. This is because in practical activities, students get a concrete picture of the situation or process that occurs.

Keywords: practicum activities, questionnaire filling method, understanding

\section{Pendahuluan}

Tahun 20013 pemerintah mengeluarkan Undang- Undang RI No 20 yang membahas mengenai Sistem Pembelajaran Nasional, Pendidikan bisa dimaksud sebagai upaya sadar serta terencana guna membuat atmosfer belajar mengajar serta prosedur pendidikan supaya peserta didik ikut aktif turut mendorong kemampuan dirinya yang lebih baik guna memiliki kekuatan spiritual keyakinan, kapabilitas, penguasaan diri, akhlak mulia, karakter, dan keahlian yang dibutuhkan dirinya, warga, bangsa, serta negeri. Berdasarkan definisi pendidikan di atas dapat terlihat bahwa pendidikan ialah sesuatu hal yang penting dan tidak akan dapat dipisahkan dari kehidupan setiap orang. Keberhasilan dari pendidikan itu sendiri dapat dicapai ketika bangsa itu sendiri berusaha untuk meningkatkan mutu pendidikan.

Setidaknya Pendidikan sendiri memiliki tiga fungsi utama yaitu pembelajaran berfungsi dalam penegakan nilai, pembelajaran berfungsi sebagai pengembang masyarakat dan pembelajaran berfungsi untuk pengembangan potensi dalam diri manusia. Pembelajaran berfungsi dalam penegakan nilai memiliki pengertian bahwa pembelajaran digunakan untuk memelihara serta menjaga agar nilai-nilai di dalam kehidupan masyarakat tetap lestari. Pembelajaran dalam fungsinya untuk 
INKUIRI: Jurnal Pendidikan IPA

Vol. 10, No. 2, 2021 (hal 145-149)

https://jurnal.uns.ac.id/inkuiri
P-ISSN: 2252-7893

E-ISSN: 2615-7489

DOI: 10.20961/inkuiri.v10i2.57258 mengembangkan masyarakat memiliki maksud bahwa pembelajaran tersebut sejatinya berasal dari masyarakat yang bersangkutan dan bertujuan untuk mengembangkan masyarakat itu sendiri. Terakhir pembelajaan berfungsi untuk pengembangan potensi dalam diri manusia memiliki pengertian bahwa pembelajaran berusaha untuk membentuk dan mempersiapkan peserta didik dalam rangka menjadi bagian dari masyarakat yang baik.

Menurut Peraturan Pemerintah Nomor 19 Tahun 2005 menilik Standar Nasional Pendidikan menuturkan jika proses belajar mengajar yang terdapat pada satuan pendidikan ini dilaksanakan dengan cara yang saling berhubungan satu sama lain, inspiratif, mengasyikkan, menarik, mendorong peserta didik agar turut berkontribusi aktif, dan menyediakan wadah untuk peserta didik dalam rangka memajukan daya cipta serta kemandirian yang cocok dengan talenta, atensi, serta pertumbuhan baik jiwa dan raga. Suatu bidang pembelajaran yang mendorong peserta didik ikut serta dalam aktivitas belajar mengajar ialah bidang kajian IPA (Ilmu Pengetahuan Alam). IPA (Ilmu Pengetahuan Alam) ialah suatu bidang kajian dimana menuntut peserta didik untuk memiliki ilmu, ide, serta konsep- konsep yang memiliki keterkaitan terhadap lingkungan di sekelilingnya yang didapatkan melewati serangkaian proses ilmiah mulai dari eksplorasi, penyusunan, serta penyampaian ide gagasan.

Dengan tuntutan seperti yang sudah dijelaskan sebelumnya, maka untuk dapat mencapai hal tersebut diperlukan suatu metode untuk mendukungnya. Salah satu metode yang digunakan agar siswa melalui serangkaian proses ilmiah adalah dengan menggunakan metode praktik. Metode praktik atau lebih dikenal dengan praktikum merupakan metode yang memiliki tujuan agar peserta dapat menelaah dan mengemukakan sendiri jawaban atau permasalahan yang dihadapinya melalui percobaan yang dilakukan. Praktikum dapat diartikan sebagai kesempatan siswa untuk menguji dan mengaplikasikan teori yang ditemukan dalam kegiatan pembelajaran menggunakan fasilitas laboratorium maupun di luar laboratorium (Suryaningsih, 2017).

Tahun 2016 Permendiknas nomor 21 mengatakan bahwa siswa dalam pelajaran IPA harus mencapai beberapa kompetensi, yaitu menerapkan metode ilmiah dan keselamatan kerja di laboratorium dalam percobaan dan pengamatan agar memahami permasalahan IPA pada berbagai objek, mengkomunikasikan hasil pengamatan, serta percobaan secara tulisan ataupun lisan, menerapkan prosedur ilmiah dalam dalam menyajikan data berdasarkan pengamatan dan percobaan berbagai objek. Hal tersebut menunjukkan bahwa diperlukannya penerapan dalam keterampilan proses sains bagi setiap peserta didik. Keterampilan proses sains peserta didik didapatkan dengan menerapkan metode praktikum.

Kegiatan pembelajaran dengan menggunakan metode praktikum diharapkan siswa dapat menguasai keterampilan proses tersebut, karena kegiatan praktikum dapat mengembangkan berbagai keterampilan seperti keterampilan kognitif, keterampilan afektif, serta yang terpenting keterampilan psikomotorik peserta didik. Pada kegiatan praktikum ini peserta didik melakukan serangkaian kegiatan seperti mengamati, menggunakan alat dan bahan, menafsirkan data, meramalkan atau menentukan hipotesis, mengkomunikasikan hasil praktikum, dan mengajukan pertanyaan. Dengan serangkaian kegiatan tersebut maka dapat dikatakan bahwa peserta didik mengembangkan semua inderanya.

Seperti yang sudah dikatakan di awal bahwa kegiatan belajar mengajar seharusnya banyak melibatkan peserta didik di dalamnya maka dengan menerapkan metode praktikum siswa tidak hanya terlihat saja, namun memiliki peran langsung dalam melakukan kegiatan praktikum. Praktikum juga dikatakan sebagai penunjang pembelajaran, karena peserta didik mendapat kesempatan untuk menemukan dan membuktikan secara langsung teori yang telah diperoleh selama proses pembelajaran yang telah dilakukan. Dengan demikian, maka peserta didik dapat lebih memahami konsep yang telah dipelajari. 


\section{Metode Penelitian}

Dalam penelitian ini digunakan metode pengumpulan data kuesioner (angket) dengan menggunakan teknik Self-Administered Questionnaires. Kuesioner adalah metode pengumpulan data yang diperoleh dengan mengajukan serangkaian pertanyaan tertulis kepada responden yang menjadi sasaran fromulir tersebut yang harus dikerjakan atau dijawab. Menurut (Sekaran \& Bougie, 2013: 147) Teknik Self-Administered Questionnaires adalah metode pengumpulan data yang memudahkan peneliti untuk mengumpulkan data yang dibutuhkan karena mencakup wilayah tertentu sehingga membutuhkan waktu yang relatif singkat. Metode pengumpulan data kuesioner (angket) dalam penelitian ini dengan disebar secara online sehingga dapat menjangkau responden yang jumlahnya banyak dan sesuai dengan masalah penelitian. Subjek responden dalam penelitian yang dilakukan adalah siswa SMP di Kabupaten Magelang. Teknik sampling dalam penelitian menggunakan random sampling dari 3 kelas paralel yaitu kelas VII, VIII dan kelas IX, kelas yang muncul dapat mewakili jumlah populasi. Instrumen pengumpulan dan analisis data menggunakan alat yang disediakan oleh Google yang membantu pengguna Google untuk membuat suatu formulir di internet yaitu menggunakan Google Formulir. Untuk mengukur skor pada angket menggunakan skala pengukuran Guttman untuk mendapatkan jawaban tegas dari responden. Jenis data berupa data kuantitatif yang didapatkan dari jawaban siswa mengenai kegiatan praktikum yang dilakukan untuk pemahamannya dalam konsep IPA dan hasil jawaban soal siswa yang telah diberikan video praktikum IPA SMP melalui video dari YouTube.

\section{Hasil dan Pembahasan}

Berdasarkan data penelitian
didapatkan dari jawaban hasil survey
"Pemahaman Konsep IPA pada Siswa SMP
dengan Kegiatan Praktikum" berupa pengisian
kuisioner yang diperoleh dari 30 siswa pada
jenjang Sekolah Mengengah Pertama (SMP).

Dari hasil pengisian kuisioner tersebut dapat dituliskan pada tabel sebagai berikut :

Tabel 1: Ringkasan Hasil Pemahaman Siswa Setelah Kegiatan Praktikum

\begin{tabular}{lcc}
\hline \multicolumn{1}{c}{ Pertanyaan } & $\begin{array}{c}\text { Jawaban } \\
\text { Tidak }\end{array}$ & $\begin{array}{c}\text { Jawaban } \\
\text { Ya }\end{array}$ \\
\hline $\begin{array}{l}\text { Apakah anda merasa } \\
\text { memahami materi } \\
\text { setelah kegiatan }\end{array}$ & 0 Siswa & 30 Siswa \\
\hline
\end{tabular}

Dari data tersebut terlihat bahwa sebanyak 30 orang siswa SMP setuju bahwa mereka merasa terbantu memahami materi dengan melakukan kegiatan praktikum yang berada di sekolah. Data tersebut berarti menunjukkan bahwa dari total responden yang mengisi kuisioner, $100 \%$ setuju mengenai pernyataan bahwa mereka terbantu memahami materi melalui kegiatan praktikum.

Pada pelaksanaan kegiatan praktikum terdiri beberapa kegiatan seperti pengendalian variabel, pengamatan,membandingkan hasil pengamatan dengan teori, serta penggunaan berbagai alat-alat praktikum. Seperti yang sudah dikatakan sebelumnya bahwa praktikum ini memegang peranan penting dalam pendidikan sains atau pendidikan IPA. Dapat dikatakan demikian karena kegiatan praktikum sendiri memberikan latihan metode ilmiah kepada peserta didik agar dapat mengikuti petunjuk yang telah tercantum dalam lembar kerja peserta didik. Dengan kegiatan praktikum, siswa akan lebih yakin akan suatu hal yang telah diberikan oleh guru, menambah pengalaman siswa dan sikap ilmiah serta hasil belajar akan lebih lama melekat pada ingatan siswa itu sendiri (Rustaman, 2005).

Dikatakan sebelumnya bahwa melalui kegiatan praktikum peserta didik menjadi lebih pasti dalam menginterpretasikan materi yang telah diberikan oleh guru. Hal ini dapat terlihat ketika praktikum dapat digunakan sebagai media untuk memperjelas suatu konsep dengan cara menggunakan bahan, alat, ataupun interaksi langsung dengan alam sekitar. Melalui kontak langsung ini peserta didik akan lebih mengerti bagaimana kondisi sebenarnya dari suatu proses 
maupun benda yang terjadi pada pokok bahasan dalam materi IPA. Dengan begitu ketika seseorang peserta didik tidak memahami materi yang sedang dibahas maka akan lebih meningkat pengetahuannya melalui pencarian informasi yang lebih lengkap dan selektif. Selain itu, di dalam kegiatan praktikum dilakukan serangkaian kegiatan yang akan mengembangkan keterampilan kognitif, afektif, dan terutama psikomotorik.

Penelitian juga dilakukan untuk membuktikan pemahaman peserta didik yang meningkat setelah melakukan praktikum. Pembuktian tersebut dilakukan dengan menghadirkan pertanyaan yang akan dijawab oleh 30 siswa SMP setelah melihat video yang dilampirkan. Dari hasil pengisian kuisioner tersebut didapatkan data sebagai berikut :

Tabel 2: Ringkasan Hasil Post-Test Siswa

\begin{tabular}{llc}
\hline No & \multicolumn{1}{c}{ Jenis Data } & Hasil \\
\hline 1. & $\begin{array}{l}\text { Jumlah siswa yang } \\
\text { tuntas }\end{array}$ & 20 Siswa \\
\hline 2. & $\begin{array}{l}\text { Jumlah siswa yang tidak } \\
\text { tuntas }\end{array}$ & 10 Siswa \\
\hline 3. & Persentase Ketuntasan & $66,7 \%$ \\
\hline 4. & Persentase & $33,3 \%$ \\
\hline
\end{tabular}

Terlihat bahwa sebanyak 20 siswa SMP dapat menjawab pertanyaan yang diberikan dengan jawaban terapung, lalu sebanyak 9 siswa SMP menjawab jawaban melayang, dan 1 siswa menjawab dengan jawaban tenggelam. Berdasarkan pertanyaan yang diberikan, jawaban pertanyaan yang benar adalah tenggelam, sehingga terlihat bahwa sebanyak 20 siswa SMP menjawab dengan jawaban yang benar dan sisanya menjawab jawaban yang salah.

Berdasarkan data yang didapatkan tampak sebagian besar siswa yang menjawab kuisioner memahami materi yang disajikan melalui praktikum yang terdapat dalam video. Hal ini sesuai dengan data yang diperoleh sebelumnya bahwa mereka setuju akan pendapat bahwa praktikum membantu pemahaman materi pada peserta didik yang diberikan oleh guru. Dalam kegiatan praktikum peserta didik nantinya dapat memperoleh gambaran secara konkret mengenai keadaan ataiu proses yang terjadi sebenarnya, sehingga tidak hanya terpaku pada gambaran imajinasi yang berasal dari peserta didi. Kegiatan praktikum juga membantu menyamakan persepsi yang mungkin saja berbeda ketika proses belajar mengajar sedang terjadi.

Hasil penelitian juga dilakukan untuk mengetahui pendapat peserta didik mengenai manfaat kegiatan praktikum yang berada di sekolah. Berdasarkan pendapat yang diberikan oleh peserta didik berpendapat bahwa melalui kegiatan praktikum mereka lebih memahami materi yang diberika oleh guru dibandingkan dengan penjelasan guru secara lisan. Kegiatan praktikum juga membuat peserta didik mendapatkan hal serta pengalaman yang baru dimana sebelumnya tidak diketahui. Selain itu, salah satu pendapat peserta didik yang mengisi kuisioner juga mengatakan bahwa melalui kegiatan praktikum dapat membentuk pribadi yang bertanggung jawab. Hal ini dikarenakan ketika pelaksanaan praktikum harus mematuhi prosedur kerja yang ada, bertanggung jawab akan alat dan bahan yang digunakan, serta bertanggung jawab akan hasil yang telah diperoleh dari praktikum.

\section{Kesimpulan dan Rekomendasi}

Berdasarkan analisis pada hasil penelitian dapat dikatakan bahwa kegiatan praktikum membantu memudahkan pemahaman konsep pada pembelajaran IPA siswa SMP. Hal itu dikarenakan pada kegiatan praktikum siswa mengetahui proses yang terjadi pada suatu konsep materi secara langsung dan nyata. Itu membantu memudahkan pemahaman konsep pada pembelajaran Kegiatan praktikum dapat menyamakan persepsi siswa dan guru terhadap suatu konsep pembelajaran. Dari kegiatan praktikum juga dapat mempengaruhi keterampilan siswa baik kognitif, dan juga psikomotorik. Hal itu juga mempengaruhi afektif siswa bahwa kegiatan praktikum juga dapat membentuk pribadi yang bertanggung jawab. 
Pada pelaksanaan penelitian ini, tentunya karya yang kami tulis ini masih banyak kekurangan dan jauh dari kata sempurna baik dari pelaksanaan hingga pada penyusunanya. Demi terselenggaranya pembelajaran yang mencapai tujuan, maka penulis menyarankan sebagai berikut :

1. Pemberian fasilitas praktikum oleh guru dapat memberikan alat-alat dan memanfaatkan bahan yang ada di sekitar.

2. Guru dalam menyusun perencanaan praktikum IPA yang akan dilaksanakan dapat mencari dari seumber-sumber yang terbaru sehingga menciptakan kegiatan yang seru dan menyenangkan.

3. Setelah kegiatan praktikum IPA, lwbih baik guru memberikan evaluasi terhadap konsep IPA yang ada pada praktikum tersebut.

4. Guru memberikan kuis atau post-test terkait kegiatan praktikum yang telah dilaksanan guna mengetahui sejauh mana pemahaman siswa dalam konsep IPA.

\section{Daftar Pustaka}

AF Suryaning, R. S. (2018). Pengembangan dan Validasi Perangkat Pembelajaran Berbasis Problem Based Learning dalam
Meningkatkan Keterampilan Berpikir Kreatif Siswa Sekolah Dasar. Jurnal Basicedu Volume 5, 2687.

Hadija, M. A. (2020). Penerapan Metode Praktikum Untuk Meningkatkan Keterampilan Proses Sains dan Hasil Belajar IPA Fisika Peserta didik pada Materi Pokok Getaran dan Gelombang Kelas VIII SMP N 2 Bungku Selatan. Jurnal Penelitian Pendidikan , 20-21.

Rustaman. (2005). Strategi Belajar Mengajar Biologi. Malang: UM Press.

Siti Aisyah, A. A. (2018). Hubungan Motivasi Belajar IPA, Hasil Belajar IPA, dan Identifikasi Perbedaan Hubungan Berdasarkan Perspektif Pesisir. Wacana DIdaktika Vol 6, 130.

Suryaningsih, Y. (2017). PEMBELAJARAN BERBASIS PRAKTIKUM SEBAGAI SARANA SISWA UNTUK BERLATIH MENERAPKAN KETERAMPILAN PROSES SAINS DALAM MATERI BIOLOGI. Jurnal Bio Educatio Vol 2, 51-52. 